\title{
NOTES
}

\section{RENEGOTIATING THE SOCIAL CONTRACT: HEALTHCARE AS A NATURAL RIGHT}

\author{
Jennifer Fahnestock ${ }^{*}$
}

\section{INTRODUCTION}

In the seminal Supreme Court case of Calder v. Bull, ${ }^{1}$ the justices began what would become an ongoing debate over the presence of an "unwritten constitution" based on the premises of natural law and societal moral obligation. The Court debated whether certain inalienable natural rights existed beyond already express or implied constitutional rights. ${ }^{2}$ Despite this debate, the federal government has yet to acknowledge an express constitutional or fundamental right to health care. Nevertheless, the debate continues to rage on as to whether each American citizen has a natural right to receive medical care in order to maintain a healthy and productive life as part of a "social contract." This debate is the underlying, and often unspoken, tension that the Obama administration, along with the Democratic congressional majority, faces regarding the overhaul of the domestic healthcare system. Through the institution of an individual mandate and other socialized-centered reforms aimed at making healthcare accessible to all, the current Democratic regime is seeking to use universal health insurance as a

\footnotetext{
* University of Pittsburgh School of Law, J.D. expected May 2011, special thanks to Christopher Sigmund for his continued support throughout the writing and publication of this piece.

1. See 3 U.S. 386 (1798).

2. $\quad I d$
} 
means to embed within the Constitution an unwritten natural right which has yet to be found.

When viewed in this light, the social contract begins to break down. Because the principles of natural law are inherently based in social contract theory, when the notion that healthcare is guaranteed as a natural right fails the underlying social contract collapses. While the exigencies of healthcare reform may remain pervasive, and while the call upon our leaders for change within the health insurance industry may remain omnipresent, any such reform must remain true to the constitutional principles and accepted premises of the social contract upon which the United States citizens have come to rely. Any attempt to force an artificial right where one does not naturally exist will operate only to compound the problems of the day.

This Note will examine selected provisions of the healthcare reform bill (the Act), ${ }^{3}$ passed and signed into law in 2010 . The Act attempts to provide universal healthcare for all persons living within the United States through the mandate of health insurance, and thereby create a natural right. Additionally, this Note will ground its analysis in the principles of social contract theory and further use those principles to discern the potential presence or absence of a natural right to healthcare.

Part I begins by developing the background and basis for constitutional rights and natural rights, while more specifically using this background to present the initial problem of whether a natural right to healthcare can exist. Part II looks at the intersection between healthcare, natural law, and the social contract. Part III examines the partisan debate surrounding the healthcare reform legislation, how health insurance is provided for as part of that legislation, and how that debate has affected the passage of legislation. Part IV explores how the healthcare reform legislation creates a breach of the social contract, and consequently shows the social and economic cost of a forced right to healthcare. Finally, Part V argues for a different kind of healthcare reform by providing for renegotiation of the social contract to return to the fundamental premises of consent and individual responsibility.

\section{PART I: CONSTITUTIONAL RIGHTS \& NATURAL RIGHTS—A BACKGROUND}

[F]or all our disagreements we would be hard pressed to find a conservative or liberal in America today, whether Republican or Democrat, academic or layman, who doesn't subscribe to the basic set of individual liberties identified by our Founders

3. The Quality Affordable Health Care for All Americans Act, 42 U.S.C. $\S 18001$ et seq. [hereinafter $A c t]$. 
and enshrined in our Constitution and our common law: the right to speak our minds; the right to worship how and if we wish; the right to peaceably assemble to petition our government; the right to own, buy, and sell property and not have it taken without fair compensation; the right to be free from unreasonable searches and seizures; the right not to be detained by the state without due process; the right to a fair and speedy trial; and the right to make our own determinations, with minimal restriction, regarding family life and the way we raise our children. We consider these rights to be universal, a codification of liberty's meaning, constraining all levels of government and applicable to all people within the boundaries of our political community. Moreover, we recognize that the very idea of these universal rights presupposes the equal worth of every individual. In that sense, wherever we lie on the political spectrum, we all subscribe to the Founders' teachings. - President Barack Obama $^{4}$

A right has been defined as a freedom owned by the people of a nation that may not legally be denied. ${ }^{5}$ More specifically, the Supreme Court has stated that constitutional rights are individual liberties granted by state or federal constitutions protected from undue government interference. ${ }^{6}$ Despite the government's ability to protect its own interests, the Constitution guards against invasion into certain private realms. ${ }^{7}$ While these definitions may be helpful to understand the meaning of a right in the abstract sense, they provide little help in concretely narrowing down exactly which rights are guaranteed (constitutionally or otherwise) and are correspondingly protected. At this point in our nation's history, the general population likely believes that their rights as citizens are both fixed and static. And, while that may be true of certain rights, a far greater majority of rights are both fluid and elusive, with a constant argument for and against protected status. As we will see, the nature of a right and how it is categorized directly corresponds with the level of acceptance it receives amongst the collective American psyche.

For the sake of simplicity, any given right, at its most basic level, can be placed into one of three distinct categories. Each category varies greatly from the others in the weight it carries in both prestige and permanency. An express constitutional right is easily the least questioned. Express constitutional rights are those explicitly enumerated; they appear on the face of our governing documents. The Founders created such rights through specific terminology the

4. Barack Obama, The Audacity of Hope 86 (2006).

5. See Definition of "Rights," Merriam-Eebster, available at http://www.merriam-webster.com (last visited Jan. 12, 2010).

6. See generally Troxel v. Granville, 530 U.S. 57, 65 (2000) (explaining that the 5th and 14th amendments offer heightened protection against federal and state government interference of certain fundamental rights and liberties).

7. Id. 
meaning of which courts subsequently interpreted and established through years of jurisprudence. The Founders expressly guaranteed these rights, such as the right to free speech, ${ }^{8}$ the right to bear arms, ${ }^{9}$ and the right to a jury trial, ${ }^{10}$ among others, to all American citizens through the creation of the Bill of Rights.

Because of their "express" nature, the Court has demanded "something higher" when the government threatens to infringe upon an express constitutional right. ${ }^{11}$ James Madison introduced this premise explaining:

[If a right is] incorporated into the Constitution, independent tribunals of justice will consider themselves in a peculiar manner the guardians of those rights; they will be an impenetrable bulwark against every assumption of power in the Legislative or Executive; they will be naturally led to resist every encroachment upon rights expressly stipulated for in the Constitution by the declaration of rights. ${ }^{12}$

More specifically, in United States v. Carolene Products, the Court recognized the unequal nature of our rights and bifurcated them as such, by creating an easily accessible framework and succinctly placing them into qualified tiers. ${ }^{13}$ First-tier rights, or express constitutional rights, are unequivocally recognized and rigorously protected by the Court. ${ }^{14}$ By contrast, the Court has shown its willingness to rubber-stamp regulation of those second-tier rights not expressly protected by the Constitution. ${ }^{15}$ In essence, those rights falling within the camp of specifically enumerated rights hold a judicial trump card. ${ }^{16}$ This category of rights "trumps" even otherwise proper assertions government power. ${ }^{17}$ These express rights are embedded within the American psyche, and clearly accepted as real and unwavering. As such, Americans understand that they hold certain personal powers which are protected from government interference. Because it does not appear on the face of the Constitution, there clearly is no express right to healthcare. One would be hard-pressed to argue otherwise; the plain language of the

8. U.S. CONST. amend. I.

9. U.S. CONST. amend. II.

10. U.S. CONST. amend. VI.

11. Robert A. Levy, Second Amendment Redux: Scrutiny, Incorporation, and the Heller Paradox, 33 HaRv. J.L. \& PUB. Pol'y 203, 206 (2010).

12. Michael W. McConnell, Natural Rights and the Ninth Amendment: How Does Lockean Legal Theory Assist in Interpretation?, 5 N.Y.U. J.L. \& LiBERTY 1, 19 (2010) (emphasis added).

13. Levy, supra note 11.

14. $I d$.

15. Id.

16. McConnell, supra note 12.

17. Id. 
Constitution does not contain even the semblance of an express constitutional healthcare right.

Moving forward, an implicit constitutional right occupies a middle ground territory. These are rights, although not expressly enumerated, that the Supreme Court has found to be so fundamental that they may not be denied. The Court has established implicit constitutional rights through the use of penumbral reasoning, stating that, "specific guarantees in the Bill of Rights have penumbras, formed by emanations from those guarantees that help give them life and substance." 18 Using such reasoning, the Court argued that implicit rights are necessary for the full protection of other constitutional rights which have been expressly guaranteed. ${ }^{19}$ Therefore, because express or first-tier constitutional rights hold such an esteemed position, the Court has extended protection to other rights emanating from them. In the overall framework, these implicit rights fall into a tier below express rights and accordingly, are protected with less vigor. ${ }^{20}$ It is important to note, however, that despite their presumably lower status, implicit or second-tier rights are entirely grounded in the specific enumerations of first tier rights. Examples of rights the Court has deemed implicitly embedded within other expressly held rights include the right to vote, ${ }^{21}$ the right to procreate, ${ }^{22}$ the right to travel, ${ }^{23}$ and the right to privacy. ${ }^{24}$ As mentioned, the Court implicitly found that each of these rights emanates strictly from an explicitly protected right. On that point, the Court has refused to extrapolate implicit rights in certain areas which cannot be said to have a basis in an express right despite the fact that the general public may consider them fundamental, although not in the legal sense of the term. Therefore, even though a right may seem fundamental in a common sense, the Court will not bestow upon a right the legal significance of the label of "fundamental" without it first deriving from our constitutional scheme. ${ }^{25}$ Examples include the right to education ${ }^{26}$ and the right to receive welfare. ${ }^{27}$

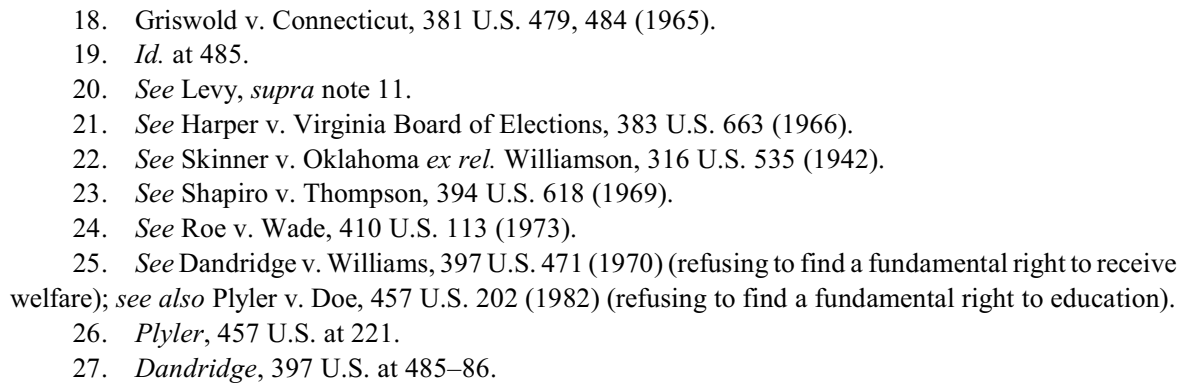


As stated above, implicit constitutional rights occupy a middle ground due to their lack of permanency. Notwithstanding the findings of the Court, arguments continue to persist over whether penumbral reasoning is a legitimate form of constitutional interpretation, and whether the Founders anticipated such expansion of the Constitution. ${ }^{28}$ Similarly, arguments continue to persist over whether certain additional liberties should be guaranteed through the use of penumbral reasoning. In the oft-quoted statement, Chief Justice John Marshall hit at the core of the debate explaining:

Its nature, therefore, requires that only its great outlines should be marked, its important objects designated, and the minor ingredients which compose those objects, be deduced from the nature of the objects themselves. That this idea was entertained by the framers of the American constitution is not only to be inferred from the nature of the instrument, but from the language .... [W] e must never forget that it is a constitution we are expounding. ${ }^{29}$

Perhaps unsurprisingly in light of Justice Marshall's emphatic view of the amorphous nature of the Constitution, implicit rights are at risk with every change of composition in the Court. Time has shown that different Justices are either more or less willing to find implicit rights hiding in the shadows of the Constitution. Even with such back-and-forth at play, there is no implicit right to healthcare; nor has one ever been found. Easily explained, the Court has refused to find such a right implicit in other provided rights.

The third and final category of rights is noticeably the most questioned and controversial. A natural right is not a constitutional right, for it is neither expressly nor implicitly found within the Constitution, yet the query remains whether such rights are nevertheless still held as protected liberties and freedoms. Not being contingent on any law, or necessary for the protection of any other right, a natural right is said to exist naturally in society. ${ }^{30} \mathrm{In}$ exploring the origins of rights, Thomas Paine defined natural rights as, "those that are inherent to a person's existence." ${ }^{31}$ It derives from nature rather than any form of positive law; its creation is entirely separate from any formation of government. A natural right is deemed a pure, moral right; its existence is thereby found in the moral obligations one citizen owes to the other, and based

28. See generally Helen K. Michael, The Role of Natural Law in Early American Constitutionalism: Did the Founders Contemplate Judicial Enforcement of "Unwritten" Judicial Rights?, 69 N.C. L. Rev. 421 (1991) (arguing that the Founders did not contemplate using the Constitution to find unwritten rights).

29. McCulloch v. Maryland, 17 U.S. 316, 407 (1819).

30. Patrick Riley, Will and Political Legitimacy 63 (1982).

31. Kristen David Adams, Do We Need a Right to Housing?, 9 Nev. L.J. 275, 289 (2009). 
on what "should" be protected for every human as both just and proper. It is inalienable not because the government has deemed it to be so, but rather because it is held by each individual apart from any positive expression or enumerated form of government. It is for this reason that natural rights are argued to be universally held and inherent in the human experience.

Natural rights are sometimes described as retained rights, encompassing "natural rights that are not relinquished, but retained by the people under the social compact." 32 The relationship between natural rights and the social contract will be explained further in Part II of this Note. For now, it is important to understand that retained rights were viewed as so primary and basic to the human existence that their existence in positive law was entirely unnecessary. Aristotle distinguished between natural justice and legal justice, contending that "the natural is that which has the same validity everywhere and does not depend upon acceptance; the legal is that in which in the first can take one form or another." ${ }^{33}$ Offering a further basis to distinguish the natural from the positive, Cicero, referring to natural law as true law, stated, "[t]rue law is right reason in agreement with nature; it is of universal application, unchanging and everlasting." 34 Later, such natural rights were explained colloquially as "the right to wear a hat and to go to bed when one pleases." Their absence in the scheme of governance was of no consequence because citizens retained the rights whether or not they were expressly safeguarded. More specifically, retained natural rights are argued to hold three features, "they are natural rather than positive, they are retained rather than relinquished, and they are unenumerated." 36

Borrowing the reasoning of the Court, a constitutional right is one which is granted by the government. ${ }^{37}$ However, this premise is the antithesis of a natural right as these rights exist independent of the government. The government cannot grant to the individual that which they already hold naturally. It therefore seems clear that a natural right is not a constitutional right. Because of this, when arguing for healthcare as a natural right, it makes little sense to ground a right to healthcare in constitutional principles. Furthermore, it would be incorrect to categorize this group of rights as the

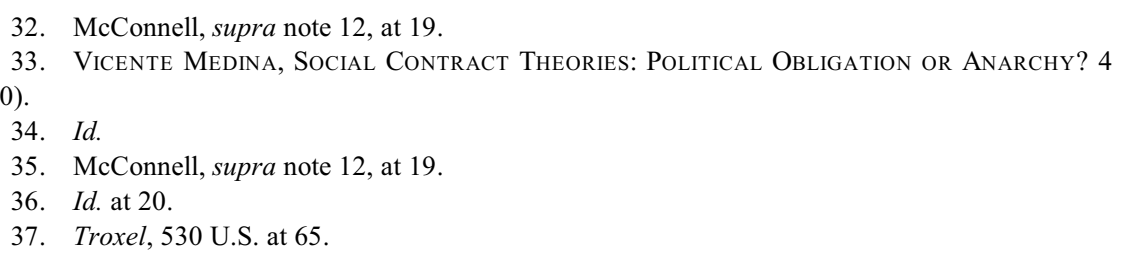


third-tier because, unlike the rights explained above, these natural rights have not been provided for in the dual framework established by the Court. Controversy surrounds whether natural rights may exist at all, nonetheless whether they can be enforced upon the government. The problem unique to natural rights then presents itself as whether these natural rights, which have not otherwise been given credence in the law, are legally enforceable?

The basis for natural rights in the American system can be found particularly within the Declaration of Independence. Thomas Jefferson, in drafting the document, built in a natural rights framework, stating that "all men are created equal" and "are endowed by their Creator with certain unalienable rights, that among these are Life, Liberty and the pursuit of Happiness. ${ }^{38}$ By the same accord, James Madison believed in natural rights and included them as a separate and distinct category when introducing the Bill of Rights. ${ }^{39}$ The concept of natural rights was well-known to the framers of the Constitution at the time they were drafting that document as well. ${ }^{40}$ The relationship that the framers saw between the Constitution and natural law is one that would reign supreme. However, it is still disputed. ${ }^{41}$

This debate over whether a right must be derived from the Constitution in order to be the supreme law has been at hand since the Supreme Court first began interpreting what the framers had constructed. In Calder v. Bull, Justice Chase and Justice Iredell began a discussion about the presence of natural rights existing outside of the constitutional scheme and what role they were to play in relation to the rights provided for in the constitutional text. ${ }^{42} \mathrm{In}$ effect, the Justices confronted the question raised earlier-whether these natural rights are, in any sense, legally enforceable?

Firmly juxtaposed from the position Justice Iredell would take, Justice Chase argued for the existence of legally enforceable natural rights and contemplated the existence of an unwritten Constitution. He believed that the Constitution should be interpreted "to contain implicitly all those individual rights that would be essential terms of a fair social contract." ${ }^{, 43}$ Relying on moral reasoning, he articulated that, despite the existence of rights provided for in the Constitution, there remain certain natural rights which are

\footnotetext{
38. The Declaration of IndePendence para. 2 (U.S. 1776) (emphasis added).

39. Daniel A. Farber, Constitutional Cadenzas, 56 DraKe L. Rev. 833, 837 (2008).

40. Terry Brennan, Natural Rights and the Constitution: The Original "Original Intent," 15 HARV. J.L. \& PuB. PoL’y 965, 971-74 (1992).

41. Id. at 975 .

42. Calder, 3 U.S. at 386-95, 398-401.

43. Edward B. Foley, The Bicentennial of Calder v. Bull: In Defense of Democratic Middle Ground, 59 Оніо Sт. L.J. 1599, 1599 (1998).
} 
guaranteed to all citizens. ${ }^{44}$ In his view, these rights derived from a social contract each citizen enters into with society at large. The Justice stated, "[t]he purposes for which men enter into society will determine the nature and terms of the social contract; and as they are the foundation of the legislative power, they will decide what the proper objects of it are." 45 According to Justice Chase, these principles of natural law could override positive law if the positive law was used in such a manner as to offend the natural law. ${ }^{46}$ In other words, the government may not infringe on those rights found to exist naturally, and any act of the legislature which conflicts with the social contract should therefore be overridden. As explained by one scholar, "[u]nder Justice Chase's view, our constitutional order precludes legislation that conflicts with the requirements of a fair social contract, 'even if not expressly restrained by the Constitution.",47

Justice Iredell entirely dismissed and disagreed with Justice Chase's position calling it "speculative." 48 He supported this contention by arguing that " $[t]$ he ideas of natural justice are regulated by no fixed standard." 99 This unrestrictive notion would permit a Justice to strike down a law on the basis of natural justice subject only to their own conceptions of right and wrong. ${ }^{50}$ Justice Iredell rejected any maxim that would allow the Court to invalidate a law "merely because it is, in their judgment, contrary to the principles of natural justice." 51 Therefore, in his view, any law that violates the written constitution would be "unquestionably void," despite the alleged existence of an "unwritten constitution." " To guard against government invasion of private rights was to define the limitations on government through fixed and set boundaries. ${ }^{53}$ These boundaries then also provide a settled framework on which the judiciary could rely when evaluating government conduct. ${ }^{54}$ Justice Iredell reasoned that the government was not constrained by natural rights,

44. Calder, 3 U.S. at 388.

45. $I d$.

46. $I d$.

47. Thomas B. McAffee, Overcoming Lochner in the Twenty-First Century: Taking Both Rights and Popular Sovereignty Seriously as we Seek to Secure Equal Citizenship and Promote the Public Good, 42 U. Rich. L. Rev. 597, 602 (2008) (internal quotations omitted).

48. Calder, 3 U.S. at 398.

49. Id. at 399 .

50. Id.

51. Id.

52. Id.

53. Id.

54. Id. 
further stating that the very fact of a written constitution is authority against the position that natural justice may be called upon. ${ }^{55}$

Looking at the issue of a natural right to healthcare against a background of Calder v. Bull, it may seem as if the Justices' concerns are not directly at stake in this context. Whereas, government is neither infringing upon a natural right, nor is government being constrained by a natural right. Instead, it seems the government is seeking to create a natural right - that all citizens are entitled to healthcare by securing health insurance for them. But, such an analysis would prove far too superficial. The contemplated issue surrounds whether a natural right to healthcare can exist, and if so, whether government would be bound to recognize it. But in this case, as acknowledged, the government is attempting to create a natural right, thereby binding itself to act in accordance with the right it has created. In a single undertaking, the government both forms the existence of a natural right, and compels its enforceability by acting as if it were already their duty to do so. As a result, government leaps into two broad assumptions: it assumes that a natural right to healthcare can correctly exist, and it assumes that natural rights are primary and legally enforceable in our constitutional scheme.

It seems clear that Justice Chase and Justice Iredell would find this contrary to both the principles of natural justice and positive law. As mentioned by Justice Chase, the existence of any natural right derives strictly from the social contract as agreed upon and entered into by the governed individuals. Noticeably, under this view, the principles of natural justice cannot be pushed upon the government when they flow from the government itself rather than the social contract. To be sure, in that situation, the government seeks to use the presence of an unwritten constitution to protect its own creation. Yet, the unwritten constitution exists for protection against government overreaching, it contains those rights maintained outside of the government and remain untouchable; it does not exist for use by the government to protect its own interests and exertions of power. Perhaps more clearly, Justice Iredell's disagreement would stem from the very premise invoking principles of natural justice. There are no fixed standards or boundaries that would control the government when it creates a right. It is restricted merely by its own discretion and desires. And yet, the existence of the Constitution itself is meant to protect against that exact manner of unchecked government action. To be sure, it is unlikely that the government would seek to restrict its action when operating in the realm of its own 
creation or "brainchild." This provokes the ultimate question of whether a natural right to healthcare exists outside any of alleged government creation. And further, whether its existence makes it the duty of the government to act in accordance with, guarantee, and not infringe upon that right.

Undoubtedly, those who would argue that healthcare deserves status as a guaranteed right do so, by placing it within the realm of natural rights. It has indeed been demonstrated that a right to healthcare does not fit within either of the other two categories, for it is neither express nor implicit. ${ }^{56}$ Specifically, in arguing for healthcare to be recognized as a natural right one scholar analogized healthcare to be:

\begin{abstract}
A human right, the existence of which derives from principles of natural law, is based in the dignity and worth of the human being. Thus, the right exists regardless of whether positive law has given it expression; a human right not recognized by positive law is a failure in the law, not an absence of the right. A just government is compelled to recognize the rights of its citizens. ${ }^{57}$
\end{abstract}

Under this reasoning, a natural right to healthcare exists regardless of whether it has been established by the Constitution. Because of its natural existence, the government must give the right due recognition.

Others, however, have recognized the difficulties in this view. Specifically, another scholar has noted three distinct problems that follow from arguing for the superiority of natural law. ${ }^{58}$ These same problems would be directly at stake in relying upon principles of natural justice to argue for a right to healthcare. Zuckert has labeled those problems: the priority problem, the substantive problem, and the foundational problem. ${ }^{59}$ Under the priority problem, the question arises as to how the duties of natural rights and natural law relate to one another and to other moral concepts? ${ }^{60}$ More simply, if the right to healthcare exists among a battery of other naturally existing rights, as they all begin to intersect, which has priority? Furthermore, would a natural right to healthcare take priority over even those first-tier express constitutional rights which have been given a judicial trump card in other contexts? Under the substantive problem, there remains a distinction between natural rights

56. See infra pp. 4-8.

57. Alison Barnes, The Various Human Rights in Healthcare, Human Rights Magazine, Fall 1998 , at 12

58. Michael P. Zuckert, Do Natural Rights Derive from Natural Law?, 20 HARv. J.L. \& PuB. PoL'y 695, 701-03 (1997).

59. Id. at 702 .

60. $I d$. 
which are negative and natural rights which are positive. Zuckert argues the existence of positive natural rights, or, in other words, the obligation to confer and provide rights, is far less clear than the existence of negative natural rights, or the obligation to refrain from infringement. ${ }^{61}$ There is a distinction between what the government is compelled to recognize and what the government must affirmatively provide for. Similarly related, the foundational problem confronts the issue of, where natural rights and natural law duties come from, if they are deemed to exist? Since they are natural, Zuckert queries, "[h]ow do we know of them, and how do we justify them?"62

As the argument goes in favor of the healthcare legislation, the government must provide health insurance in order to secure the natural right to healthcare. And, the government must do so because the worth of all humans demands it. However, this reasoning is faulty. Certainly, it would be backwards to argue that the value and dignity of all human beings is not worthy of being sustained through healthcare. In other words, the contention of this counter-argument is not that human beings are not worthy of maintaining a healthy life. On the contrary, every human being is worthy of the right to life, liberty, and the pursuit of happiness regardless of their status in the social hierarchy. ${ }^{63}$ Yet, it is difficult to see how ones' worth by itself can automatically translate into certain rights that government is compelled to recognize. Citizens may be deserving of far more than they have, but our government does not dole out provisions which have not otherwise been explicitly or implicitly recognized based solely on a citizen's worth. There needs to be some bridge or connection between ones' natural existence and worth, and the rights a government provides. This link comes in the form of a social contract. More specifically, in our form of government, our Constitution exemplifies this social contract. A right to healthcare does fit within the framework of our Constitution.

\section{PART II: HEALTHCARE, NATURAL LAW \& THE SOCIAL CONTRACT}

Justice is the end of government. It is the end of civil society. It ever has been and ever will be pursued until it be obtained, or until liberty be lost in the pursuit. In a society under the forms of which the stronger faction may as truly be said to reign as in a state of nature, where the weaker individual is not secured against the violence of the stronger; and as, in the latter state, even the stronger individuals are

61. $I d$.

62. $I d$.

63. The Declaration of IndePendence para. 2 (U.S. 1776). 
prompted, by the uncertainty of their condition, to submit to a government which may protect the weak as well as themselves. . . - -Alexander Hamilton ${ }^{64}$

In order to understand the broader impact of the Act, it is important to appreciate the basis of natural rights and the subsequent interplay between natural rights and the larger social scheme. The existence of natural rights derives directly from the corresponding theory of the existence of a social contract. Examining natural rights through the lens of the social contract, it becomes clear that creation of a natural right to healthcare is based on flawed and unsustainable reasoning. Because of this flawed reasoning, the healthcare legislation based on such unstable principles cannot succeed.

The social contract specifically deals with the individual citizen's relation to the larger community, and the distribution of power between the individual and governing society. Human beings as individuals begin in a state of nature, entirely unregulated, holding certain inalienable natural rights. ${ }^{65}$ The social contract exists for the preservation of these and other rights. By entering the contract, "people chose to relinquish [certain natural rights] in order to promote the good, prosperity and safety of society." ${ }^{66}$ By the same account, under the social contract, people retain certain natural rights which the contract itself is meant to protect.

The theory advocates that each person's moral and political obligations are dependent upon a contract or agreement between all citizens to form a greater good, or a society. ${ }^{67}$ Society is thus, created through establishing this contract, whereby all citizens - the parties to the contract-agree to live together in harmony for their mutual benefit. ${ }^{68}$ In this sense, it is important to distinguish the harmony created by the contract from the alleged harmony created by communal living and communistic-organization. The contract exists to maintain basic political rights. Corresponding duties derived from the contract are placed on the individuals who have contractually obligated themselves. Unlike other maxims behind socialism or communism, at the basis of the contract is the protection of the individual, rather than the greater good. The individual enters the contract to ensure opportunity to pursue their own gain. Individuals promote the order and prosperity in society recognizing it to be the means through which they will achieve their own goals. Hence, the

\footnotetext{
64. The Federalist No. 51 (Alexander Hamilton).

65. MedinA, supra note 33, at 30.

66. McConnell, supra note 12, at 19.

67. Medina, supra note 33, at 16-17.

68. See generally Michael Lessnoff, Social Contract 54 (1986) (explaining that contract as "multilateral covenants" that authorize a sovereign government to preserve the peace).
} 
contract protects the opportunity to success rather than guarantees the achievement of it.

The first modern philosopher to articulate a detailed social contract theory was Thomas Hobbes. According to Hobbes, individual self-interest prevented the creation of a society. ${ }^{69}$ By this account, individuals were in constant competition with each other. With a scarcity of resources, individuals' interests were never entirely fulfilled or secure. In an unregulated scheme, the interests of one's neighbor presented a constant threat because these contradictory interests could take precedent should the neighbor decide to assert them. Because of this, there was a consequent need to join together in some organized fashion so that every citizen could receive full and equal access to opportunities. The social contract, to Hobbes, was an occurrence during which individuals came together and ceded some of their individual rights so that others would also relinquish some of theirs. ${ }^{70}$ This resulted in the establishment of society, and by extension, the establishment of a ruling government. The creation of government resulted in a sovereign entity meant to preserve these new collective rights that would now provide the basis to regulate societal interactions. ${ }^{71}$ The government, therefore, acted as a fiduciary of sorts, holding individual rights in trust for their security and fruition. Thus, the framework for government was limited by the rights it was established to protect.

The philosopher Rousseau, formulated his own conception of the social contract, referring to it as an "exchange . . for a more secure" life, ${ }^{72}$ and a "covenant . . . which serves as a basis for all other rights." represented a "reciprocal commitment" which established the basis for two distinct relationships. ${ }^{74}$ Medina explains that " $[t]$ he social contract has been associated with two different concepts: the concept of the contract of government, and the concept of the contract of society." "75 First, the contract regulated the relationship between each individual citizen and the government. ${ }^{76}$ It created the basis for a legitimate political authority. ${ }^{77}$ In this

69. MedinA, supra note 33, at 12-13.

70. Id. at 15 .

71. See id. at 17.

72. Jean-Jacques Rousseau, The Social Contract 77 (Maurice Cranston trans., Penguin Books 1968) (1762)

73. Id. at 50 .

74. Id. at 62 .

75. Medina, supra note 33, at 5.

76. Rousseau, supra note 72 , at 62 .

77. Medina, supra note 33, at 5-6. 
sense, the contract restricted government action that may infringe on the individual. Additionally, the contract restricted individuals from overpowering and overtaking the government. Second, the contract regulated the relationship between each individual citizen and his fellow citizens. ${ }^{78}$ This relationship served as the basis for societal order-organizing individuals into a greater collective body. Within this distinct relationship, the contract prevented individual interests from inhibiting the general welfare of the community. In return, the contract prevented community interests from preceding the interests of the individual.

Rousseau reinforced the view of Hobbes that, "the government is formed as an association of people with a desire to be governed in order to achieve certain goals, namely, 'the protection and prosperity' of the members of the association." 79 The contract, however, was not impenetrable. The covenants laid down in the contract could be broken if a certain degree of unity was not maintained. ${ }^{80}$ A contractual breach becomes inevitable when sectional societies and particular interests begin to exert influence over greater society. ${ }^{81}$ Gilmore argued that Rousseau's underlying contention was that small disparities in opinion were of little consequence, "sectional based issued cannot prevent the general will of the people ... from prevailing." ${ }^{82}$ However, differences which split across broad bases of society and comprehensive sectional disagreements pitted against the general will of the people prevented contract purposes from being realized.

Rousseau further discussed the details of that which emerges out of the social contract - a ruling government. In explaining the import of a governmental structure, Rousseau suggested a primitive form of checks and balances. He argued that a system is deficient when the legislative and executive branches become united without a sufficient degree of independence between the two. ${ }^{83}$ As Rousseau described it, the deficiency emerged when the prince and the sovereign are embodied in the same branch; such a scheme symbolized a "government without government." 84 As support for this, Rousseau reasoned that, "[i]t is not good that he who makes the law should

78. Rousseau, supra note 72 , at 63.

79. Brian Gilmore, American Rousseau: Barack Obama and the Social Contract, 35 T. MARSHALL L. REV. 9, 20 (2009).

80. RoussEAU, supra note 72 , at 150 .

81. Id.

82. Gilmore, supra note 79 , at 20.

83. RoussEAU, supra note 72 , at 112.

84. Id. 
execute it, or the body of the people should turn its attention away from general perspectives and give it to particular objects." 85

The philosopher John Locke expounded Hobbes' and Rousseau's exploration of the creation of government, but Locke's views were specifically contrasted with Hobbes. While Hobbes argued that near-absolute authority was granted to the government by the terms of the contract, Locke believed that government derived its legitimacy directly from the consent of the governed. ${ }^{86}$ Under Locke's configuration, men must consent to two separate acts for authority to be legitimate. First, they must "consent[ ] to make one community or government ... and make one body politic, wherein the majority have a right to act and conclude the rest." ${ }^{\circ 7}$ Second, the majority achieves this by placing its "supreme power" in the legislature. ${ }^{88}$ Therefore, the government lacks authority to act under the social contract when its action does not promote the common good or the will of the majority. In conjunction with Locke's disagreement, different objections to Hobbes's early formulation arose including that "Hobbes misused the term 'right' when he described it as a pure liberty with no correlative duty." 89 On the contrary, a right projected a reciprocal attaching duty upon others which prevented their outside interference and infringement with that right. ${ }^{90}$

In development of social contract theory, as recognized by Zuckert, Locke laid down three basic premises:

First, Locke said that he meant 'right' to be that sort of moral claim that carries along with it claims to exclusivity. Second, Locke said that there is such property in or by nature; that is, human beings possess natural rights of the sort that imply natural duties. Finally, Locke concluded that justice is, therefore, by nature. ${ }^{91}$

Although each individual takes ownership over their personal rights, for a contract party's natural rights to be protected by the social contract, that party must agree to protect the natural rights of others as well. While a natural right is exclusively held by an individual, the implication remains that certain duties must be correspondingly imposed under the contract.

85. Id.

86. Zuckert, supra note 58 , at 725 .

87. ERnest Barker, Introduction to Social Contract: Essays by Locke, Hume, AND Rousseau xx-xxi (photo. reprint. Oxford Univ. Press 1967) (1947).

88. Id. at xxi.

89. Zuckert, supra note 58 , at 727.

90. Id.

91. $I d$. 
Despite emphasis on the common good, at the basis of the social contract is self-preservation. The contract represents a coming together of separate men, each willing to guard the interests of another, so that their own interests may be guarded in return. It is upon this premise that the more modern view of the social contract often speaks in terms of duties and obligations, rather than just rights conferred. In order for one citizen's natural rights to be protected, it becomes necessary for that citizen to protect the natural rights of other parties to the contract, thereby pooling certain powers to be exercised collectively. Therefore, the individual citizen must assume certain duties in order to receive the benefits and protections he desires. The contract, then, is a means of establishing reciprocal rights and duties, privileges and responsibilities as basis of the state. ${ }^{92}$

These theories of government based on a social contract were later incorporated into the United States governing ideology principally through James Madison. ${ }^{93}$ More specifically, the Founders relied heavily upon the works of Locke while establishing the American democratic form of government. ${ }^{94}$ As evidence of this, Thomas Jefferson believed that the preservation of certain natural rights was an essential part of the social contract, and that consent of the governed was fundamental to any exercise of governmental power..$^{95}$ The social contract at work within the United States is specifically embodied in the form of our Constitution, which lays out the rights of citizens and the responsibilities of government. Through the Constitution, government was formed and became the necessary medium to secure the rights of a free and equal American people. The Founders arguably believed that the American social contract would adequately protect natural rights as they were understood. The contract they fashioned, however, did not contemplate government acting outside its bounds of authority, and going beyond that which was necessary to secure the interests of the people it was meant to protect.

With this background, we can delineate three main provisions which provide the basis for the social contract: the hallmark of consent, reciprocity, and moral obligation. Each provision represents a mutually binding term in the contract. If one of the three provisions is not adhered to, the result is a material

92. Richard Ascraft, Locke's Two Treatises of Government 38-39 (1987).

93. See Notes of Debates in the Federal Convention of 1787 Reported by James Madison (C.C. Tansill ed., 1987).

94. Andrew C. Spiropoulos, Rights Done Right: A Critique of Libertarian Originalism, 78 UMKC L. Rev. 661, 663 (2010).

95. Id. at $667-68$. 
breach to the contract. In this context, when the government itself breaches the contract by failing to adhere to any of the above provisions, its actions are no longer constitutionally grounded. Because the government is a creation of the contract itself, when the contract breaks down the source of government power becomes illegitimate.

Primarily, in order to enter into any contract, consent is required from both parties. By traditional contract standards, one who argues for the validity of any contract must primarily point to both the offer granted and the acceptance given. ${ }^{96} \mathrm{~A}$ contract cannot be valid unless all parties voluntarily agree to it. ${ }^{97}$ This agreement may be formed explicitly or implicitly, as long as it is given without coercion. In order for consent to be given voluntarily, the reasons for entering the contract must remain viable. By extension, the necessity of consent is inherently grounded in the freedom of choice- a core American value. Citizens may be politically obligated to act in certain ways or obey certain rules, removing a degree of their autonomy and choice, only because they have previously chosen to obligate themselves. If involvement is forced, the contract will not remain a binding document. In that event, those who are forcefully involved will choose other methods to protect their rights, even if it means reverting backwards, pulling away from society-at-large, and doing so on an individual basis.

Without consent, the strong ties to the general community, which once existed exclusively due to the contract, will break down. It follows, that the social contract is formed and maintained only by the intentional and deliberate union of the citizens who enter into the contract for specific purposes. The basis of societal order requires this mutual assent. The contractual promise acts as a prima facie obligation to obey the law constructed by the contract. Therefore, voluntary agreement, which by necessity requires the absence of coercion, is the essence of the hallmark of consent.

Similarly, in order for the social contract to thrive, all citizens who choose to contract must be willing to forgo certain privileges in order to receive the protections they seek, and once formed, consent remains binding only so long as the other party does not violate the terms of the contract. By this account, the social contract requires a certain amount of reciprocity between the parties involved in the contract. Without reciprocity, there would be a lack of incentive to enter into the contract in the first place. Practically speaking, it seems highly unlikely that a party would bind itself to a contract that would

96. Restatement (Second) of Contracts $§ 22$ (1981).

97. Id. at $\S \S 174-77$. 
require the party to shoulder all the burden of the contract terms alone without receiving any countervailing advantage for doing so.

Again, referring to basic contract principles at law, any valid contract requires consideration that includes the mutual exchange of benefits and detriments to the contracting parties. In the context of the social contract, the consideration follows in a less tangible form, but nevertheless remains real and present. The individual gives up certain liberties for the benefit of the community. But, the individual's willingness to forego does not stem from a purely generous frame of mind. In return, the individual receives certain benefits from the community, such as the protection of their rights. In order to bind an individual to the contract, Medina argues that three principles must be satisfied, all grounded in the principle of reciprocity:

(1) the state and its institutions must be generally beneficial; (2) most people must generally act compatibly with the state's institutions (including its laws), so that if we disobey we take unfair advantage of their compliance . . .; and (3) we must voluntarily and openly accept, in a real sense, the benefits provided by the state. ${ }^{98}$

It follows, then, that citizens consent to the terms of the contract for the advantages it confers. The obligation conferred on citizens, in return, requires them to live up to the bargain made. However, the advantages must be mutual, and not one-sided, in that each party is receiving rights adequate to compensate for those he is giving up.

Lastly, the social contract distinguishes itself from general contract principles in one final way. It finds its basis in moral obligation. As explained earlier, the consideration holding up the social contract is less tangible than the consideration generally underlying most contracts. Whereas services performed or monetary provisions may be the basis for obligation in most cases, under the social contract, the basis for obligation finds its origination in moral reasoning. Although the individual seeks to protect his own rights, it is also out of concern for the greater good that the individual chose to enter into a societal agreement. Rather than just conferring on the state a blanket right to command, the contract generates moral reasons, stemming from a sense of justice, for each individual to obey the law. ${ }^{99}$

The benefits derived from the contract have been, in essence, requested. During the bargaining process, each individual voluntarily accepted the terms of the contract so long as their needs were appropriately provided for. This

98. MEdinA, supra note 33, at 151.

99. Id. at 152 . 
means that, hypothetically speaking, individuals came to the bargaining table with certain non-negotiable demands. They requested that certain provisions be made by the contemplated governmental scheme for the protection of their rights before they would willingly consent. Therefore, once an individual accepts the benefits he has previously requested, he will feel a sense of moral obligation, rather than entitlement, to see to it that the other parties to the contract receive the benefits they have requested as well. This feeling of entitlement is absent because the parties have previously foregone certain privileges in order to create the contract. As noted further, "[a] person is under an obligation to do his part as specified by the rules of an institution whenever he had voluntarily accepted the benefits of the scheme or has taken advantage of the opportunities it offers to advance his interests, provided that this institution is just or fair." 100 Individuals hold this moral obligation because they understand that individual success cannot be realized in the absence of success of others, as well.

In summary, citizens hold this social contract between each other and with the government. The government represents the organization and order of society which has been chosen and created by the contract. Therefore, the government represents a microcosm of the social contract in that certain powers are granted to government for protection of the individual, and by extension, the greater good. Government exists purely at the pleasure of the people who enter into the contract. In particular, our governmental framework is established through the Constitution, which sets its parameters as contemplated by the contract. Consequently, as an entity arising out of the contract, the government has a duty to exercise its powers wisely and pursuant to the purposes and terms of the social contract. By the same account, if the government attempts to force to the social contract to its limit, the contract will inevitably breakdown. Breach of the contract occurs when the government acts outside of the reasons for its establishment. The current proposed healthcare legislation causes a breakdown of the social contract by forcing the existence of a right that is not naturally rooted, thereby breaching each of the three terms which form its basis.

\section{PART III: HEALTHCARE REFORM LEGISLATION \& THE PARTISAN DEBATE}

We have a mission. We have a mandate. We have a moral obligation to lead this Nation into a new era where health care is a right and not a privilege. Now is the time. Be on the right side of history, the right side of the sick, the right side of the 
vulnerable. We have been tracked down by the spirit of history. If we fail to act on health care, if we fail to do what we must do, history will not be kind to any of us. So I say to you, my colleagues: be not afraid. Be not afraid. Be of the courage. The time is always right to do what is right. On this day, at this moment, answer the call of history, and pass health care reform, and pass it today. Pass it now for the people of this country.- Rep. John Lewis (D-GA) ${ }^{101}$

In an attempt to enact unprecedented healthcare reform legislation, in 2009, the 111th House of Representatives began what would prove to be a tumultuous process seeking to pass sweeping healthcare reforms. Subsequently in 2010, after much debate, the Congressional majority passed the Senate-version of the bill with a vote that was split almost exactly down party lines. ${ }^{102}$ The Quality Affordable Health Care for All Americans Act (the "Act") was signed into law by President Obama, who had advocated for such sweeping healthcare reform since the time of his presidential candidacy. ${ }^{103}$

Looking back as a precursor to both the legislation and Congressman Lewis's above-quoted statement, during the 2008 Presidential Debate, thenSenator Obama was asked whether healthcare was a "privilege, responsibility or right?" ${ }^{104}$ Contrasted with his opponent Senator John McCain, then-Senator Obama responded:

I think it should be a right for every American. In a country as wealthy as ours, for us to have people who are going bankrupt because they can't pay their medical bills - for my mother to die of cancer at the age of 53 and have to spend the last months of her life in the hospital room arguing with insurance companies because they're saying that this may be a pre-existing condition and they don't have to pay her treatment, there's something fundamentally wrong about that. ${ }^{105}$

It was this mentality which served as a baseline, and it was under this leadership, that the Democratic majority pushed forward to enact healthcare legislation that was centered on an ideology that viewed healthcare as right, rather than a "responsibility" or a "privilege."

Based on the above statements, it can be inferred that Democrats, including Congressman John Lewis, view this legislation as an opportunity to

101. 111 Cong. ReC. H12857 (daily ed. Nov. 7, 2009) (statement of Rep. John Lewis).

102. Final Vote Results for Roll Call 887 (Nov. 7, 2009), http://clerk.house.gov/evs/2009/roll887 .xml.

103. See Obama Signs Health Care Overhaul Bill, With a Flourish, N.Y. Times.com (Mar. 23, 2010), http://www.nytimes.com/2010/03/24/health/policy/24health.html.

104. Transcript of Second McCain, Obama Debate, CNN.COM (Oct. 7, 2008), http://www.cnn.com/ 2008/POLITICS/10/07/presidential.debate.transcript/ [hereinafter Debate Transcript].

105. Id. 
make healthcare a right to all United States citizens. It is important to note, however, that in this regard, Congressman Lewis and his colleagues speak of making healthcare a right not through any constitutional rights, but rather, through a moral obligation. ${ }^{106}$ As demonstrated, healthcare as a right is entirely without constitutional support. ${ }^{107}$ It is neither expressly provided for nor has it been implicitly found. Therefore, in order to argue for healthcare to assume status as right, the proponents of the Act embed healthcare within our system of rights by claiming it has a higher natural existence. Throughout the debate period for the proposed legislation, opponents consistently questioned Democrats about where they found the constitutional authority to enact such a Bill creating a right to healthcare. But, because the right is not constitutionally based, Democrats were unable to provide a satisfactory answer. This is why they forced the right as a natural one which would seemingly exist outside of the constitutional structure. Congressman Lewis purposefully speaks of history's call upon the Congress and their mandate to act, implying that the right to healthcare would be a certain one of those inalienable rights naturally existing outside of government for centuries.

As further support, in then-Senator Obama's statement, he fails to invoke any constitutional right from which a right to healthcare may derive, but rather speaks about how in "a country as wealthy as ours," it would be morally inequitable to allow people to worry about paying for their medical treatment. ${ }^{108}$ This talk of equities similarly connotes a sense of fairness and moral obligation rather than strictly constitutionally-principled reasoning. This thinking exemplifies the general sentiment among Act proponents. In this way, the Democratic Congress, along with the President were not attempting to impute healthcare as a constitutional right, but embed healthcare as a natural right by invoking the ideals of the social contract to justify its protection as such.

Perhaps unwittingly, by invoking natural right status, the Democrats are forced to also accept the proposition that healthcare existed as right prior to their actions. Using the principles established by Locke, the absence of a constitutional right to healthcare does not result in the absence of a right altogether, but rather results from a failure of the government to secure such a right. Arguing again from a social contract standpoint, John Locke has stated that the natural rights of individuals "are not bounded by the positive limits of

106. 111 Cong. ReC. H12857 (daily ed. Nov. 7, 2009) (statement of Rep. John Lewis).

107. See supra Part I.

108. Debate Transcript, supra note 104. 
kingdoms or commonwealths." 109 As a result, Democrats seek to rectify this oversight that has existed since the creation of the American form of government. In doing so, they go beyond merely recognizing a right to healthcare that cannot be infringed, but affirmatively provide for the right.

To be certain, the Act makes no outright assertion that healthcare is now a right. Neither this, nor similar wording can be found within the plain language of the bill; a declaration without more would be of little assistance in this context. One could declare healthcare as a right without seeing any meaningful change in the number of citizens with proper healthcare. There lies a multitude of intervening factors standing between a bare declaration of healthcare as a right in an abstract sense and a real endowment of healthcare upon each and every citizen. Democrats have attempted to implement this socalled natural right, providing for more than just a declaration by securing health insurance for all citizens. The Democrats sought to streamline healthcare by making sure that every American citizen received the same quality of care through use of the same quality insurance without inequitable disparities. The right, in the Democrats' view, should not depend on ones' income and ability to afford it. Ensuring that each person has an acceptable level of health insurance likewise ensures that each person will have a right to use the full panoply of health services available in our country so as to maintain good health. Insurance, therefore, represents the means through which healthcare and the right is realized.

The Quality Affordable Health Care for All Americans Act attempts to create and extend a natural right specifically through the following provisions discussed. Initially, the most significant, and yet troublesome, provision is the requirement of health insurance. The Act creates an individual mandate which requires all lawful residents enroll in a healthcare plan, purchase, and maintain qualified insurance coverage. ${ }^{110}$ "Qualified insurance coverage" is a term-ofart defined by the Act as the bare minimum of coverage permissible. Minimum coverage is further defined depending on which market a particular individual falls into-specifically relating to whether they purchase the insurance themselves or whether it is provided by their employer. ${ }^{111}$ Therefore, not only does the Act force individuals to enter the market and purchase

109. AshCRAFT, supra note 92 , at 179

110. Staff of Republican S. Pol'y Comm., 111th Cong., Legislative Notice: The Quality Affordable Health Care for All Americans Act, No. 28, at 6 (Dec. 2, 2009) (explaining provisions of the Act), available at http://rpc.senate.gov/public/_files/L28HR3590HealthCare120209ac.pdf [hereinafter Legislative Notice].

111. Id. at $7-8$. 
insurance, it also dictates the acceptable amount of insurance coverage they must purchase. Each plan offered and purchased in any insurance market must meet certain requirements prescribed by the Act. ${ }^{112}$ In the face of this mandate, individuals who do not have insurance, or those who do not have "acceptable" health insurance as defined by the Act, will be assessed a penalty of up to $\$ 750.00$ per individual, phased in over three years beginning in $2014 .{ }^{113}$ All citizens must attest on their tax returns that they have obtained the appropriate level of benefits. ${ }^{114}$ Similarly, insurers must also report to the IRS. ${ }^{115}$

This individual mandate is the first attempt to create universal health insurance, embedding in each citizen their natural right to healthcare. A natural right occurs, theoretically speaking, only at the point when all individuals retain it and no one is excluded. If certain individuals do not hold the right, it cannot be inherently held by all people. As the theory goes, if the government can force all citizens to retain insurance, then the right can be secured because of its universality. It automatically jumps to the assumption that the resulting access to healthcare becomes enshrined with the status of a right merely because everyone holds it. The need behind this requirement is that the government will be able to control the substance of the right so long as it can dictate the bounds in which it occurs. It obligates people to procure the right for themselves based on the government's determination of how the right should be shaped.

Essentially, through the mandate, the government is saying, "this is your right, and this is what your right will have to look like- now go out and buy it." Up to this point in time, such an approach of compelling individuals to buy their right in order for it to come into existence is unprecedented. Individuals are forced to spend their money on this right, whether or not it is a right which they value. Furthermore, by assessing a penalty on those who choose not to buy-in, individuals will engage in a variation of cost-benefit analysis to determine whether the right is worth it. In many cases, "the levels of these fines are generally too low to cause a rational individual to insure." 116 Citizens, then, will have the ability to negotiate away the right, leaving some people with it and some people without it, based on their individualized economic determinations. If certain members of the population accept the

112. Id. (explaining the requirement of "essential health benefits").

113. Id. at 7 .

114. $I d$.

115. Id.

116. Id. at 7 n. 25 . 
penalty rather than the right, the problem of whether the right can be truly universal again arises.

The Act contains certain provisions which may be equated to a "hardship waiver" for those who are unable to independently afford the mandate. In essence, an individual may claim that obtaining insurance is unaffordable in their circumstances and a forced purchase would amount to a hardship. To accommodate this scenario, there is a full exemption from the mandate "if the premiums for the lowest-cost plan available exceed 8 percent of income ... and for individuals below 100 percent of the Federal Poverty Level." 117 Eligibility for unfunded Medicaid coverage is expanded for individuals up to 133 percent of the Federal Poverty Level-a 40 percent increase to the Medicaid rolls. ${ }^{118}$

For others claiming hardship that do not fit within these categories, the Act provides tax credits, or subsidies, for individuals falling between 133 and 400 percent of the Federal Poverty Level. ${ }^{119}$ These "affordability credits" are offered to assist lower-income individuals so that they might comply with the mandate and purchase the appropriate insurance coverage. The credits derive from a sliding scale based on the ability to pay, and are phased out as income level rises. ${ }^{120}$ The scale is fashioned so that individuals will pay no more than $9.8 \%$ of their income on insurance premiums. ${ }^{121}$

The credits are completely phased out when income reaches 400 percent of the Federal Poverty Level. ${ }^{122}$ Therefore, individuals are eligible for a subsidy if they earn less than 400 percent of the Federal Poverty Level, and they are not offered affordable coverage through their employer. ${ }^{123}$ In other words, an employee offered employer-sponsored care will not be eligible for the credits so long the employer option is affordable. The Act has defined "affordable" as a plan which covers more than 60 percent of the actuarial value, and has premiums less than 9.8 percent of their income. ${ }^{124}$ Further, "actuarial value" is defined as "the percentage of the average expected medical costs than a plan will cover." ${ }^{, 25}$ For example, a plan which has an actuarial value of $60 \%$ will cover approximately $60 \%$ of the plan-holder's

121. Id.

122. See id.

123. Id. at 9-10.

124. Id. at 10.

125. Id. at 9 n. 30 . 
actual medical bills. Individuals who do not fall within these parameters will be independently responsible for compliance with the insurance mandate, and by extension, will also become responsible for those claiming hardship. According to the House Committee on Education and Labor, these provisions create a shared responsibility between the individual, the employer, and the government in securing healthcare for all Americans. ${ }^{126}$

At this point, it is important to note that individuals with employer-based coverage are automatically ineligible to receive a subsidy to assist with the payment of their health insurance, regardless of their income. Also, even for those eligible, the government subsidy does not come without strings attached. In order to receive affordability credits, individuals must purchase their health insurance plan through the newly-created state Health Benefit Exchanges ("Exchange"). ${ }^{127}$ By 2014, states must establish an Exchange and force the participation of all insurers operating in the state. ${ }^{128}$ The Exchange would be analogous to a large marketplace where a variety of merchants, in this case, the insurers, come to show their wares, in this case the qualified health plans. Exchange administrators will determine whether the plans offered meet minimum requirements necessary to be deemed a "qualified health plan" and be eligible for sale to individuals and small employers. ${ }^{129}$

The purpose of the Exchange is to provide further regulation of the plans being offered in it. For example, each plan is given a rating based on its quality and price. ${ }^{130}$ Additionally, the government controlled Exchange has the authority to exclude certain plans and dictate prices. To make the Exchange plans a more affordable option, the premiums and rates would be negotiated by the government within previously determined limits. ${ }^{131}$ Thereafter, insurers must submit justifications for any potential increase in their premiums and go through a bureaucratic review process. ${ }^{132}$ Most alarmingly, an Exchange administrator is given what seems to be almost absolute discretion to refuse offering any insurance plan not in the "best interests" of qualified

126. House Comm. on Ways and Means, Energy and Commerce, and Educ. and Labor, 111 th Cong., America's Affordable Health Choices Act (July 14, 2009), http://edlabor.house.gov/documents/111/pdf/ publications/AAHCA-BILLSUMMARY-071409.pdf.

127. Legislative Notice, supra note 110, at 4.

128. Id. at 8 .

129. $I d$.

130. $I d$.

131. $I d$.

132. Id. 
individuals. ${ }^{133}$ The Act leaves the "best interests" standards entirely undefined. ${ }^{134}$

The requirement of healthcare additionally extends beyond individuals to ensure that insurance is not overlooked by any entity. In this sense, employers too are faced with certain mandates. Again, all insurance coverage offered by employers must meet certain minimum benefit requirements laid out in the Act based on what insurance market the employer-based coverage would fall into. ${ }^{135}$ Employers with more than 200 employees must automatically enroll employees for health insurance coverage. ${ }^{136}$ Employers with more than 50 employees are assessed a "free rider tax" for each employee who obtains insurance through the Exchange rather than the employer, and receives a tax credit (subsidy) to do so. ${ }^{137}$ The employers' penalty differs depending on whether or not they offer the minimum essential coverage to their employees in-house through their own self-sponsored program. "If an employer has more than 50 full-time employees (FTE), does not offer coverage, and has at least one FTE getting credit, then the penalty is $\$ 750$ per FTE." ${ }^{138}$ On the other hand, "[i]f the employer has more than 50 full-time employees, offers coverage, and has at least one FTE eligible for a subsidy in the Exchange, the employer pays the lesser of $\$ 3,000$ for each of those employees receiving a credit or $\$ 750$ for each of their total full-time employees." ${ }^{\prime 39}$ This means that under this second situation, even though an employer offers coverage, that coverage is not deemed to be affordable for at least some employees. ${ }^{140}$ While a tax credit is available for small-businesses to encourage them to provide employer-sponsored plans, that credit is available only to those employers who purchase insurance through the Exchange. ${ }^{141}$ Additionally, the credit phases-out based on employer size, and would only be available for a maximum of two years. ${ }^{142}$ Thus, additional individuals would be forced into the Exchange via their employer who initially seeks a tax incentive. However, once firmly rooted in the Exchange, the matching benefit wears off, leaving

\footnotetext{
133. $I d$.

134. $I d$.

135. Id. at 7.

136. Id. at 18 .

137. Id. at 10 .

138. Id.

139. Id.

140. See id.

141. Id. at 11.

142. See id. at 11-12.
} 
employers and employees within the Exchange footing the entire bill without assistance.

The tax punishes an employer for free riders assumedly, because the government wishes to obligate employers to provide for their employees' the right to healthcare in the first instance. However, many experts predict that this tax will cause more employers to decide to drop employer-sponsored coverage. ${ }^{143}$ As explained earlier, certain employees will inevitably involve themselves in the Exchange to receive the benefit of subsidies, especially if the government subsidies offered are so generous that the employer cannot compete with them. Therefore, if an employer is forced to pay a penalty, whether they choose to supply coverage or not, in some cases, it will result in a more prudent business decision to drop coverage entirely. Supposedly, when seeking to provide for a universal natural right, this was not Congress' intent.

During the initial legislative process, the Democratic Congress attempted to pass what would have amounted to a "public-option" which would have competed with private entities within the Exchange. ${ }^{144}$ The public-option terminology describes a government-run health insurance plan not driven by profit motive as those in the private sector. ${ }^{145}$ However, it was highly unlikely such a version of the bill would have passed due to the heavy public opposition. While the final version of the Act does not contain a publicoption, its passage is no less problematic. Instead, Congress adopted the Exchange system, and granted it enough regulatory control to be satisfied. Despite the absence of the public option, the Exchange still signifies an unbridled degree of government jurisdiction over the healthcare industry. It seems that the Exchange provisions are effectively the first step in a move towards a single-payer system, with a viable public option being the only intermediary step between what has been signed into law and what is to come. Moreover, the Exchange will not succeed and for many of the same reasons, a public-option would fail.

The institution of the individual mandates and the Exchange will have far reaching effects beyond just offering a lower-cost health insurance option to certain segments of the population. The discretionary oversight afforded to the public sector to set rates and dictate premiums in the private sector will further result in lower quality of care to individuals. Privately-run insurance companies will be strained to fit their services within the specified premium

143. Id. at 10 .

144. See Senator Christopher Dodd, A Strong Public Option, http://dodd.senate.gov/multimedia/ 2009/PublicInsuranceOption.pdf.

145. Id. 
limits allowable by the Exchange. In many cases, this will mean cutting services in order to cut costs. Capping of costs, in many cases, will result in the capping of care. Additionally, since companies in the Exchange will have less available financing within which to operate, the Act allows for a kind of strict rationing of benefits, putting a ceiling on the amount of benefits individuals and families may receive. Private insurers will unavoidably offer the mandated bare minimum and seek to cut corners wherever possible.

This public vs. private dichotomy has created a highly charged partisan debate. The Republican opposition to the legislation argues that the public sector control provided for by the Act will create a reduced ability to compete among the private sector. ${ }^{146}$ In this view, the freedom within the private sector will operate to keep costs down, increase efficiency and innovation, and further result in increased accessibility to services sought. ${ }^{147}$ In contrast, the public sector is often associated with vast bureaucracy, unresponsive to individual needs and concerns. Interestingly, this is the opposite of protecting individual interests which the Act purports to achieve. By ordering that all insurances plan must offer " $x$ " services and charge " $y$ " price, the Exchange eliminates the possibility of healthy competition between the insurers. In such a situation, there can be no competition when the industry operates with such uniformity; knowing that the playing-field is even, there is no incentive to outperform. Rather than making such sweeping mandates, private sector discretion allows citizens to get the best quality for the amount they are willing to pay. Generally speaking, competition is the most efficient means by which to lower costs while increasing coverage. For instance, when " $A$ " insurance company sees " $\mathrm{B}$ " insurance company offering a service at a lower price, "A" is given incentive to find a way to offer those same or more services at an even lower rate so as to divert customers away from "B." Thus, the most effective system is based on competition; a race to see which can provide the best quality for the best cost.

Increased regulation inevitably results in less goods and services, and by extension, less choice. Many private insurers will likely be forced out of the market due to an inability to comply and compete with the lower rates of the Exchange. The Exchange will be funded, in part, through various taxes and penalties on those using private insurance by outside operating companies. ${ }^{148}$ The Act purposefully creates for an excise tax on what has been termed

\footnotetext{
146. See GOP Solutions for America, Health Care Reform, http://gopleader.gov/UploadedFiles/ Summary_of_Republican_Alternative_Health_Care_plan_Updated_11-04-09.pdf.

147. $I d$.

148. Legislative Notice, supra note 110 , at 14-16.
} 
"Cadillac plans," or in other words, those private plans which administer the best coverage available. Health insurance plans that exceed $\$ 10,200$ for individuals and $\$ 27,500$ for families are subject to a 40 percent tax. ${ }^{149}$ This creates a clear incentive for those generally higher-income individuals who would be subject to the tax to buy into the Exchange. By squeezing out the independent private insurer, individuals with the ability to pay are subjected to the effects of government compulsion and unwittingly moved into the government-controlled market. Those who have been forced, without much choice, to buy into Exchange plans will fund those low income individuals already within the Exchange who cannot afford the costs of healthcare. These individuals, moving from their private or employer-based insurance plans, will thereafter subsidize those individuals receiving affordability credits or hardship waivers in the Exchange. The government, then, is relying on those moved into the Exchange who do not receive a tax credit, to pay for others entering the Exchange because of the offered government subsidy. In reality, the government's subsidy is funded by higher income individuals rather than the government itself. Because of this, it is estimated that the Act "requires nearly 14 million Americans to purchase unsubsidized insurance that is more expensive than they could get under the current law." ${ }^{150}$ The Act proponents have euphemistically termed these results as "cost sharing levels that ensure access to all." 151

The end result is to appropriate private healthcare plans under government supervision, providing for strict oversight and rationing. Through excessive regulation and commandeering, the government has usurped an exceptional level of control over the healthcare industry. Yet, the government cannot forego maintaining this level of influence because it is means by which they pay for and provide for their forced right. Unable to manage the private sector in the same fashion, the government justifies its increasingly hegemonic expansion of public supremacy.

\section{PART IV: THE COST OF A FORCED RIGHT \& “BREACH” OF THE SOCIAL CONTRACT}

This is not a debate about prices, coverage or choosing doctors. This is ultimately about what kind of country we are going to be in the 21 st century. America is not just a nationality. It's not just a massive land from Hawaii to Maine from Wisconsin to

149. Id. at 15. Amounts have been changed to reflect the actual numbers reflected in the Act.

150. Id. at 4.

151. See House Committee on Education and Labor, supra note 126. 
Florida. American is an idea. It's the most pro-human idea ever designed by mankind. Our Founders got it right when they wrote in the Declaration of Independence that our rights come from nation and nature's God, not from government. Should we now subscribe to an ideology where government creates rights and is solely responsible for delivering these artificial rights and then rations these rights? My friends, we are fast approaching a tipping point where more Americans depend upon the federal government than upon themselves for their livelihood, a point where we, the American people, trade in our commitment and our concern for our individual liberties in exchange for government benefits and dependencies. Rep. Paul Ryan (R-WI) ${ }^{152}$

Based on the foregoing, it is easy to conclude that a natural right to healthcare as provided by the Act is logically impossible. Because of this, the Act creates and forces a right rather than allowing it to come to fruition naturally. Any natural right which has been retained by the people derives strictly from the social contract as agreed upon and entered into by the governed individuals. By the same account, any right whose protection is justified by the contract cannot derive from the government itself. Government cannot force a natural right, place it within the protection of the social contract, and then seek to hold itself accountable for the right it created.

In this sense, government uses the contract to protect its own creation, whereas, the social contract, as originally conceived, was established to protect those rights that individuals retained after certain other rights were relinquished for the common good. A retained right cannot be created posthoc. The fact that it was retained makes clear that it was already in existence at the time the agreement was put in place. Forcing a natural right causes a breakdown in the social contract because that contract was established for the protection of rights against outside interference. It is axiomatic that government is not permitted to use the social contract to justify its own assertions of power by arguing that its power protects a natural right, and is thereby permitted by the contract. Quite the contrary, natural rights are described as "bright line limits on government action allowing each individual a district and substantial sphere of private action free from state coercion." 153 Consequently, natural rights are limits on government action, not an avenue for the government to absorb more power and become further embedded in private life. Put rather simplistically, healthcare as a right, is not constitutional, nor can it be natural. Thus, it is being forced upon the social

152. Rep. Paul Ryan, 111 Cong. House Floor Debate (Mar. 21, 2010), available at www.cspan.org.

153. Spiropoulos, supra note 94. 
contract. Forcing a natural right in this manner causes a breach in the social contract.

Breach of the social contract is rather clear when a right is constitutionally grounded because the existence of the right and its parameters are predetermined. However, when the right is not constitutionally grounded, the argument for breach becomes more difficult. The social contract was established for the protection of those retained natural rights. And, the government created as a by-product of the contract was ordained with the task of protecting against infringement of those rights. Therefore, the government has the power to act, under the contract, when those actions would be consistent with the contract's purpose.

In the context of the Act, the government is creating a right, and thereafter, arguing that it is natural in order to justify its usurpation of power. The government deems the right to healthcare to be natural in order to argue that it is forced to act in accordance with that right. In other words, the government argues that its actions are acceptable under the contract because it is protecting a natural right and it is bound by the act accordingly under the principles of natural law. Otherwise, the government would lack the power to act in such a manner under the contract. Yet, this is where the problem presents itself. Without a right already in existence, the government lacks the power to act under the contract to protect a right. If there is no right to protect, the government cannot act. It cannot create a right and then argue it must be protected per contract terms. For that reason, the government initially lacks the power to act under the contract because its authority does not stem from anywhere except its own creation. The Act stretches the contract beyond all conceivable means.

Healthcare, as a right provided for by the Act, is not a natural right as the founders or John Locke would have understood it. ${ }^{154}$ In their view, natural rights existed prior to the formation of government; they are, by definition, natural. Since a right to healthcare did not exist naturally, the right is forced. Therefore, any oversight on the part of the founders to fail to expressly protect a natural right would be of no consequence if a right was truly inalienable. And, while the founders may not have contemplated a right to healthcare, what they did contemplate was a government based on natural rights, not government-created rights. A right that is created is, undoubtedly, not natural. Since there is no government in the pre-political state of nature, there cannot

154. Andrew Busch, Is Healthcare a Right?, Claremont Institute, Mar. 2010, available at http://www.claremont.org/publications/crb/id.1607/article_detail.asp. 
be a right to government-supplied health care in the state of nature. The right must exist naturally, before the creation of the government, such as the rights to life and liberty.

The right to life is distinct from a right to healthcare. If a right to healthcare is natural, Democrats are forced to also accept the proposition that healthcare existed as a right prior to their actions. This view is strained because healthcare as a right did not exist prior to government creation in the Act. Before the provisions of the Act came into play, a portion of the population did not naturally have healthcare services available to them. Healthcare itself does not exist naturally, but is an outgrowth of civilized society. Despite this, as Congressman Ryan poignantly points out, the Act creates a forced and artificial right which flows directly from the government rather than nature. ${ }^{155}$

In the time post-Calder, the Court has been rather opaque regarding where it stands on the existence of natural rights and their interaction with our form of government. Since Calder, the Court has not again confronted the express question of whether there are natural rights which are legally enforceable and have the power to constrain the government to act in accordance with them. Nor has the Court ever confronted the issue of whether there exists a right to healthcare, natural or otherwise. Ruminations on natural rights will appear from time to time, generally as dicta without any conclusively clear holding. In spite of this, if the Court were to confront the explicit question we face today, it seems likely that the result would be a hesitance pull from outside our constitutional scheme and confer healthcare with the status of a natural right. ${ }^{156}$

In his dissent in Cruzan v. Missouri Dept. of Health, Justice Stevens accepts the idea that " $[\mathrm{t}]$ here is a fundamental natural right expressed in our Constitution as the 'right to liberty' ...."157 Justice Stevens, then, seems to accept the proposition that at the very least, the inalienable rights to life, liberty, and pursuit of happiness are protected by our constitutional framework. In defining natural rights as such, the question becomes whether the right to liberty encompasses healthcare. Furthermore, in his dissent, the right to liberty was described in the context of the freedom to live without government infringement. ${ }^{158}$ Therefore, in Justice Stevens' view, it seems that

155. Rep. Ryan, supra note 152.

156. In fact, the Court will confront a variation of this issue as the states have challenged the constitutionality of the individual mandate in the Act albeit on different constitutional grounds.

157. Cruzan v. Missouri Dept. of Health, 497 U.S. 261, 333 (1990) (Stevens, J., dissenting).

158. Id. 
the natural right to liberty does not necessarily confer additional rights, but rather prevents rights already secured from being infringed upon or taken away. The creation of a yet-undeclared natural right to healthcare cannot easily be squared with this view.

Soon after Calder, a lower court confronted the possibility that natural rights may be legally enforced as an outgrowth of the Privileges and Immunities Clause in Corfield v. Coryell. ${ }^{159}$ The lower court held among the natural rights protected by that Clause was a citizen's right to travel among the several states and hold the same natural rights as she moved throughout the nation, irrespective of where she was located. Reflecting on this reasoning, the Supreme Court in Hague v. Committee for Industrial Organization, explained:

\begin{abstract}
At one time it was thought that [the Privileges and Immunities Clause] recognized a group of rights which, according to the jurisprudence of the day, were classed as "natural rights"; and that the purpose of the section was to create rights of citizens of the United States by guaranteeing the citizens of every State the recognition of this group of rights by every other State. ${ }^{160}$
\end{abstract}

Yet, those rights secured by the Privileges and Immunities Clause are expressly and implicitly found within the Constitution, and as such, are not natural. Shortly thereafter, the Court discarded the natural rights theory that underlay Corfield. ${ }^{161}$ As such, the Supreme Court recognized this flaw in the lower court's reasoning.

Lastly, in G. D. Searle \& Co. v. Cohn, the Court hinted at another view regarding the existence of natural rights. In declining to find a right to the shield provided by a statute of limitations, the Court stated " $[\mathrm{t}]$ heir shelter has never been regarded as what now is called a 'fundamental' right or what used to be called a "natural' right of the individual." 162 From this perspective it seems that the Court views natural rights as encompassed in the doctrine of fundamental rights. It specifically analogizes the fundamental right to the natural right as they are one in the same. It appears to suggest that the Court believes that natural rights were merely the precursor to the modern doctrine of fundamental rights. Therefore, if the Court remains consistent in this view, their interpretation represents a segment of rights which are distinct from natural rights as generally understood. The Court appears to use the 'natural right' terminology loosely without commanding the extensive history supplied

159. Corfield v. Coryell, 6 F. Cas. 546 (No. 3,230) (C.C.E.D. Pa. 1823).

160. Hague v. Committee for Indus. Organization, 307 U.S. 496, 511 (1939).

161. Id.; see also Supreme Court of New Hampshire v. Piper, 470 U.S. 274, 281 n.10 (1985).

162. G. D. Searle \& Co. v. Cohn, 455 U.S. 404, 408 (1982). 
by the theories of Rousseau, Hobbes, and Locke. By equating natural rights to the doctrine of fundamental rights, the Court, in essence, does no more than refer to constitutional rights implicitly found and protected. Moreover, as it is clear at this point in time, the Court has failed to find a fundamental right to healthcare, and by extension, would not find a natural right either.

In Justice Goldberg's concurrence in Griswold v. Connecticut, he argued that the Court is not permitted to declare rights as fundamental by looking solely to their own personal preferences. ${ }^{163}$ Rather, Justice Goldberg argued that in order to discern which rights exist outside of those expressly guaranteed, the Court must look to the "traditions and collective conscience of our people to determine whether a principle is so rooted ...." $164 \mathrm{He}$ further reasoned that "the inquiry is whether a right involved such a character that it cannot be denied without violating those fundamental principles of liberty and justice which lies at the base of all our civil and political institutions."165

In Griswold, Justice Goldberg was in search of some contractual basis to serve as a foundation for an implicitly created fundamental right. The same reasoning can be applied when trying to discern whether Congress may create a natural right to healthcare. If it is argued that the right to healthcare is natural, the legislature cannot create such a right in light of their personal and private notions. While it may be true that the power of the legislature derives from a fundamentally different origin than the power of the Court, it still holds true that both branches are confined by the same principles in determining the existence, or non-existence, of any right to be ranked as fundamental or natural. What is more, Congress, in contrast to the Court, is considered to be more politically accountable and constrained by notions of popular opinion and ideology. Therefore, any right deemed to be natural, must primarily exist naturally and be "so rooted" in the "traditions and collective conscience of our people."166

Justice Goldberg's reasoning in Griswold can be safely extended to the natural rights context because he articulates a similar concern that Justice Iredell expressed many years before in Calder. To be sure, a distinction can be made that Justice Goldberg spoke about implicit rights, where as Justice Iredell argued against the enforceability of natural rights. Nevertheless, the underlying problem remains constant in both contexts. As citizens of the United States, we accept the presence of the Constitution as our authoritative

163. Griswold v. Connecticut, 381 U.S. 479, 493 (1965) (Goldberg, J., concurring).

164. Id., quoting Snyder v. Massachusetts, 291 U.S. 97 (1934).

165. Id., quoting Powel v. Alabama 287 U.S. 45 (1932).

166. See supra note 165 . 
governing document because we believe that we understand its limitations and boundaries. We can point to specific provisions which either permit government action or restrain it. A government permitted to govern by the principles of natural justice and natural rights is entirely unchecked in the same way the Court would be unchecked if they adjudicated according to their own discretion and not the law. Such unimpeded power of manipulation would lead to a governing body wholly without limits - a completely arbitrary form of government.

Relating back to the priority problem, substantive problem, and foundational problem presented in Part I; relying on natural law to create rights outside of our constitutional scheme results in an unworkable structure turning our governing institutions into convoluted shadows of what they were intended to be. It renders the Constitution void as our governing document if it can easily be supplanted by calling on natural rights without some form of express authority.

Reform-voting Democrats may argue in response that a natural right to healthcare is necessary for preservation of the right to life. As such, it would be grounded in tradition and the collective conscious as a clear extension of the right to life which has been accepted both expressly and implicitly from the beginning of the nation. However, as noted by one scholar, proponents of this argument conflate two notions that are "superficially complementary," but actually distinct: "the duty to help others in mortal danger, recognized by doctors themselves in the ethics of their profession, and the right to forcibly extract help from others." 167 The first represents a "noble code cultivated in a free society and accepted by free people who voluntarily take responsibility for their fellows." 168 The second is a "form of conscription in which some individuals forcibly commandeer the services and resources of others for what is fundamentally their own private benefit." 169

While our healthcare industry may have a moral obligation to supply all of the appropriate services necessary to save a life, the failure to adhere to this moral duty does not automatically result in the denial of the right to life. The right to life is denied when citizens actively inhibit another's ability to continue living, for example, by taking from the individual their food, shelter, or most disturbingly, their life. This is different from a citizen, or the healthcare industry, failing to assist another with the exercise of their right.

167. Busch, supra note 154 .

168. $I d$.

169. Id. 
The failure to give another food or shelter is not the same as taking another's food or shelter away from them. In the first case, the right to life persists in the absence of the added provisions. In the second case, it does not. In any event, the argument is described as "disingenuous," because the right to healthcare goes far beyond a right to life. ${ }^{170}$ "[I]nasmuch as liberals are not contending for equal access to lifesaving procedures; they are contending for guaranteed issue of the whole panoply of health services."

Looking beyond the elucidations of the Court despite the lack of precedent, it seems unmistakable that there exists no natural right to healthcare because of its inconsistency with the basic natural rights doctrine. The Democratic Congress is attempting to thrust upon the American people healthcare legislation by arguing that all Americans share an equal right to be insured. But in this context, insurance does not exist outside of the government's creation. By the very definition of natural rights, it is contradictory to their existence to argue that one can be created through the Act. A right which is forced is not a natural right. While it may be more arguable that one has a right to health, a right to specific healthcare services does not exist in a state of nature; the government must affirmatively provide for it.

People may resist the notion of being insured. As it currently stands, many Americans choose not to purchase healthcare for a variety of different reasons. If, in fact, there exists a natural right to healthcare, no person would be able to deny such a right. Natural rights exist inherently in the human condition, and the ability to deny the existence of any government-created right lies directly in conflict with the view that its existence is inherent, and therefore, natural. Its preexisting character begs the question, if no government has the ability to deny any citizen a natural right, then why must the government force such a right?

By the strict terms of the Act, each individual and employer is forced to secure the right by either acquiring or offering the proper health insurance. The right therefore, must be negotiated and purchased, and the right cannot exist without all members of society buying it. By analogy, one has right to purchase and own a gun. This Second Amendment right exists for every citizen whether or not they choose to actually engage it by purchasing and owning a gun. A similar argument can be made for most of our rights which have been secured; they exist whether or not we as a people choose to exercise 
them. A woman who has chosen to forgo her right to obtain an abortion still retained the right to make that choice. An atheist retains the freedom to exercise a religion despite their current abeyance and disbelief.

By contrast, the same choice cannot be said of a natural right to healthcare. If one person decides not to exercise their right, and does not buyin by obtaining an insurance policy of acceptable standards, the entire system fails and a universal right to healthcare does not exist. The right to own a gun, the right to exercise ones' religion, or the right to have an abortion is different from a right which requires one to affirmatively have healthcare provided for them. If healthcare services are not actually supplied or if the right is not, in fact, engaged, the right does not exist. If citizens can negotiate away their right by assessing whether the penalty meant to enforce the mandate provides enough incentive to procure insurance, the government does not end up with a situation where everyone holds the right.

Under the new system, certain individuals will accept the penalty rather than the right. In this context, those who accept the penalty and ignore the mandate do not retain a right to healthcare which simply has not been exercised. By contrast, because of its affirmative nature, the right to healthcare cannot survive in a vacuum. In this case, the right to healthcare cannot exist without positive enumeration in the law because it must be affirmatively provided for. And yet, a natural right is one which is retained-the characteristics of retained rights being that they are not positive and are not enumerated. That Congress had to force the right by writing it into our positive law by way of the Act is a strong indication that the right is not natural.

Once again, by analogy, while some members of society may not have the means or the desire to purchase a gun, their right exists nonetheless. Should they ever secure the proper funds, they may exercise their right at that time. As it stands now, for those members who cannot afford health insurance, they lose more than just the chance to exercise their right in a real way. Just as with the gun, they may surely purchase healthcare if they later obtain the money to do so. But, this purchase does not amount to a right precisely because the individual sought out the care on their own and without the government backing. During the interim, when the individual did not have the money to buy insurance, the right was non-existent. Unlike our other rights, there is no free-floating choice or option that remains in existence even when the right is not being exercised. A natural right is not created by choice, but an individual retains the choice whether to pursue the right. Healthcare gains the status of a right, under the current policy choices, only upon the time when the health insurance is positively provided for by the government and actually secured 
by all. Under this thinking, the failure to exercise ones right creates the loss of the right, whereas the right comes into existence only upon the purchase of the right.

If the right is not universally held, it cannot be deemed natural, something the Act proponents would like it to be. A right that is natural inheres in all people without exception-it is universal, by definition. Yet, it has been recognized that even under the Act universality is lacking-24 million Americans will still remain uninsured and without coverage. ${ }^{172}$ What's more, certain individual may reject the right by accepting the penalty instead.

The system created by Congress provides for the natural right of some only by ensuring that others will too exercise their right. Without this universality, the entire design scheme fails. Therefore, for the first time, the exercise of one's right directly affects the ability of others to exercise their right. Universality is achieved only by forcing all individuals to attain health insurance. Without certain purchasing individuals exercising their right, the right of others simply cannot exist. However, this is utterly inconsistent with the generally accepted principle that a right is individually owned and cannot be dependent on the community.

It is unlikely that there will be enough purchasing individuals in the Act's system to subsidize those who cannot afford to make the purchase. This, once again, produces healthcare coverage that is not universal - the antithesis of the government's plan. In an attempt to avoid this result, Congress has provided penalties for those who fail to exercise their right. Such a premise has never before been attempted because of its draconian and illogical results. Because natural rights exist entirely apart from the law, it is contradictory to call upon the law for its enforcement. Furthermore, the penalty for not exercising ones' natural rights contradicts the essence of a right - which implies that an individual has discretion and choice whether or not to engage it.

Additionally, because some citizens already had adequate healthcare preAct, the creation of a natural right becomes even more problematic. If the right existed naturally, all citizens would have retained it. The government would not have to use the Act to provide the right for some but not others already accounted for. Therefore, the social contract did not entirely fail to secure the natural right, if it can be created and defined as such. It has obtained access to healthcare for citizens through the private sector rather than through government coercion. 
There also lies a distinction between what the government is compelled to recognize as a right and what the government must actually provide. It presents itself as an issue of a right to equal access of healthcare vs. a right to have it guaranteed by the government. By recognizing a right as one that requires protection, the government does no more than prevent its infringement. The government guarantees each individual's ability to exercise their right, but does not supply the right for them.

In this case, the government does more than just acknowledge a right to equal access. The Act goes beyond recognition of a pure right to healthcare and ensures that each individual actively exercises their right. However, under this dichotomy of equal access vs. equal results, the scheme presented in the Act is not a viable option in light of the history of our social and political institutions. The social contract operates as a restriction of government action; therefore, our rights protected under the contract operate by constraining the government, but do not mandate government action in and of itself. The social contract exists to protect, and this does not necessarily entail a corresponding obligation to provide.

Tracking a similar problem, in Harris v. McRae, the Supreme Court rejected the argument that the right to abortion translated into a positive government obligation to fund abortions for the poor. ${ }^{173}$ Any legitimate assertion of authority lacks the ability to mandate the implementation of a right. "The recognition of political authority does not entail a right to command, but only a right to punish transgressions of the law." 174 This sort of thinking has been accepted as a basic premise from the founding of our nation.

The framers were more concerned with creating a framework of rights that protected "freedom-from" rather than "freedom-to." 175 "Freedom-to" may be equated with an affirmative obligation to provide, whereas "freedom-from" may be equated with a duty to refrain from interfering. Explained by one scholar, "Americans of the founding era were deeply committed to individual rights, which typically consisted of what we call negative rights-freedom from." ${ }^{\prime 176}$ By contrast, a right to healthcare, as is provided for by the Act, runs contrary to this scheme as it would fall more directly in line within a "freedom-to" framework.

When looking at the social contract exclusively in terms of the healthcare legislation, there is no right for the social contract to protect because,

173. See Harris v. McRae, 448 U.S. 297 (1980).

174. MEdinA, supra note 33, at 153.

175. McAffee, supra note 47 , at 610 .

176. Id. 
correspondingly, there is no natural right to healthcare. Because of this, the Act breaches the three main terms of the social contract as discussed in Part II: consent, reciprocity, and moral obligation. Degradation of each of these terms results in a material breach, and as well-known under the principles of contract, a breach cannot come without certain costs. Breach has come in the form of the Quality Affordable Health Care for All Americans Act, and even the slightest adherence to any of the provisions as proposed will result in a breach that will be costly for both the individual citizen and the government.

Initially, there is a clear lack of voluntarily-given consent. If citizens are not receiving the benefits of a protected right, they will not consent to enter into the social contract. Because healthcare cannot be a protected right, any consent to the enactment of this healthcare reform legislation will be artificial and compulsory. As noted above, entering into any contract requires the freedom to choose, and consent cannot be binding unless freely given. Succinctly stated by one legal scholar, "[f]or consent to bind a person, there must be a way to say 'no' as well as 'yes' and that person himself or herself must have consented ... . [N]o person can literally consent for another."177 Clearly, consent to buy into the healthcare right is not freely given when health insurance is required through a mandate. Additionally, consent is further inhibited because the failure to abide by the mandate results in a penalty. A person does not consent to that which is mandatory; they have no power to say yes or no. Additionally, because of the penalty an individual is punished for failing to exercise their right. Under the Act, the ability to consent and the value of individual choice has been stripped away.

It may be argued that an individual voluntarily consents to the mandate when they decide to follow its terms rather than the terms of the penalty. Even though the individual may choose to accept the penalty rather than the mandate, this does not restore the individual's freedom of choice. Such choice between a mandate and a penalty is superficial; for even if an individual chooses the penalty, their choice is still circumscribed by the mandate - the penalty is an outgrowth of the failure to adhere to the mandate. For consent to be a consequential act, individuals must be given the opportunity to consent primarily to the mandate in the first instance. As it stands now, any choice that is made occurs within the parameters already laid down by the mandate; the individual is never given a choice to accept or deny the terms of the mandate itself. Because there is no meaningful consent, the right is forced in the truest sense of the word. 
Protection of a right to healthcare was not contemplated as part of the bargain that was agreed to by the terms of the contract. The insurance mandate endeavors to create a natural right and enlarges the public sector, both going far beyond what individuals have contracted for. When government begins acting outside of the bargain as initially agreed upon, the contract is breached, and those governing do so without the consent of the governed. The Supreme Court has explicitly explained the import of this standard, stating: "[w]e set up government by consent of the governed, and the Bill of Rights denies those in power any legal opportunity to coerce that consent. Authority here is to be controlled by public opinion, not public opinion by authority." 178 Hence, the government lacks the authority to shape the opinion of the public through use of coercive and derisive means. Self-determination and self-government represent the basis of the social contract and our government. Inescapably, people will adhere to contractual terms more strongly if they are able to control what those terms will signify. Governing according to the consent of citizens represents a well-established principle of law that weighs heavily in the mind of the Supreme Court when faced with significant constitutional issues surrounding the framework of our government. But, the current Congressional majority has lost sight of this principle, governing according to their own whims. Through the Act, the principle becomes more of a fanciful ideal than a practical form of governance.

Under a system such as ours, organized based on a "consent of the governed" standard, the government has no authority to act when their actions are rejected by the governed. For the executive and legislative branches, a loss of legitimacy becomes inevitable when they act in this capacity. In the case of the current legislation, the governing bodies have acted without authority or the backing of public opinion resulting in a distinct failure of the political process. When the government acts without consent in the face of such high opposition, such actions are beyond their delegated powers and illegitimate.

A political authority is legitimate only if: (1) we are allowed to choose who is going to govern us ... (2) we have fair access to political power, and (3) we are allowed to be both negatively free, in the sense that the state does not interfere in our private domain, and positively free, in the sense that the state provides use of the necessary means to develop our capacities as autonomous persons with a sense of dignity. ${ }^{179}$

178. W. Va. State Bd. of Educ. v. Barnette, 319 U.S. 624, 641 (1943).

179. Medina, supra note 33, at 152 (emphasis added). Providing the means to succeed is not the same as ensuring that each individual will succeed. 
Further, as argued by Angus, the desire to achieve a fair allocation of healthcare resources depends precisely upon cultural beliefs and social attitudes. ${ }^{180}$ And yet, the American people have decisively rejected the shape that healthcare reform has taken. According to a CNN poll, approximately $59 \%$ of Americans oppose the legislation with that number slowly and consistently rising as more time passes. ${ }^{181}$ Discomfort with the mandates could be seen in boisterous, and at times hostile, town hall meetings through the Untied States in the summer of 2009. ${ }^{182}$ A further example of this can be seen through the actions of attorney generals across the nation who filed a lawsuit challenging the legislation, specifically the mandate, as unconstitutional immediately after passage. ${ }^{183}$

Moving forward, the Act also creates a problem in the terms of shared responsibility and reciprocity. By forcing individuals into insurance policies they may not desire, and providing punishment for lack of adherence, the legislation places the community over the individual. Per the terms of the social contract, the interests of the individual and the community are to be placed in a sustainable balance, with the protection of individual interests remaining at the heart of the contract. Individuals agree to protect community interests only as means to ensure their own interests will be protected. Sustaining reciprocity within the social contract is achieved by avoiding an excessive concentration of power, whether found in the public or private interest. The idea of a proper balance relates back as far as the theories of Rousseau who warned against the combination of a prince who also acts as the sovereign. ${ }^{184}$ Specifically, under the American form of government, it is supposed to be the individual who acts as the sovereign rather than the collectivity represented by government. ${ }^{185}$

Therefore, the reciprocal nature of the contract relies on the delicate balance between the individual and the community, with each individual holding the upper hand to shape the community interests. Thus, the onus falls

180. Douglas Angus, Some Thoughts on Rights and Responsibilities in Healthcare, 11 NAT'L J. Const. L. 261, 263 (2000).

181. CNN Poll (Mar. 2010), http://www.redstate.com/jrichardson/2010/03/22/cnn-poll-59-percentnow-in-opposition/.

182. Specter Faces Hostile Audience at Healthcare Forum, CNN (Aug. 11, 2009), http:// www.cnn.com/2009/POLITICS/08/11/specter.town.hall/index.html.

183. Complaint, Florida ex rel. McCollum v. U.S. Dep't of Health \& Human Servs., No. 3:10-cv-91 (N.D. Fla. Mar. 23, 2010), available at http://msnbcmedia.msn.com/i/MSNBC/Sections/NEWS/A_Politics/ healthcare.pdf (at this point, the case has survived the first hurdle).

184. RouSSEAU, supra note 72 , at 112.

185. United States v. Lee, 106 U.S. 196, 208 (1882). 
evenly on each individual so that the greater good might be realized. However, in the case of the Act, that balance has been broken because the community has entirely overpowered individual interests. The individual interest succumbs to the needs of the greater community, creating a disincentive for the individual to maintain compliance with the mandates of the community.

Although it may seem differently, under the Act the government is no longer protecting the interest of the individual. Rather, government protects a generalized conception of public health that looks past the well being of any single citizen within the collective body. This distinction can be made in terms of a generalized interest vs. an individualized interest. When presented in this light, it is argued that "individual rights are inherently at odds with the collective public health." ${ }^{" 186}$ Healthcare itself focuses on individual wellness, whereas public health is concerned with promoting optimal health of the population as a whole. ${ }^{187}$ Focusing on the public health rather than healthcare undervalues and sacrifices the ability to provide the best possible care to each and every individual citizen in a singular capacity.

Provisions in the Act, specifically those that govern the plans within the Exchange, attempt to control pricing and plan rates which affect the amount of care that can feasibly be provided. Making health insurance more affordable for the community at large does not result in a corresponding benefit to any one single person. Whereas previously all healthcare decisions were made between doctor and patient, such decisions will now be made according to economic considerations - allocation and rationing of medical services based on general availability. The government must determine who will receive what care out of a scarce pool of resources. A natural right to healthcare, then, is not an unlimited right if it is constantly being defined and evaluated.

Some are only entitled to " $\mathrm{x}$ " amount of the right depending on various factors such as age and economic standing. It follows, that the government will be confronted with determining what one human life is worth as compared to the indiscriminate interest in protecting all human lives. There is a clear lack of reciprocity and mutual benefit between the public interests and the private interests to be balanced. Furthermore, additional problems are presented in terms of reciprocity because, for many, the Act will result in a forced investment with varied, and often lacking, individual returns.

186. Elizabeth Weeks Leonard, The Public's Right to Health: When Patient Rights Threaten the Commons, 86 WASH. U. L. REv. 1335, 1344 (2009).

187. Id. at $1344-34$. 
Generally speaking, the social contract follows a basic return on investment theory. Each citizen agrees to contract, or invest, with the aim of receiving specific returns. In the absence of such returns, the contracting parties would not have agreed to offer their consideration for the bargain. When this occurs, individuals will seek an organizational scheme that more tightly conforms to their needs and wants by pulling out of the contract that has failed to adequately protect their individual interests.

Under the Act, those with the most returns have invested the least, and vice versa, those with the least returns have invested the most. In this context, returns can be directly pinned to the effects of the affordability credits, or those provisions which subsidize the cost of healthcare for some, but not all. Based on a subjective conception of what is affordable, an individual's returns under the Act are dependent on ones' income and ability to afford the mandate. The cost of a healthcare plan increases for those who are able to afford it in order to compensate for the decreasing costs of those who are unable to afford it. The individual is pitted against the community, leaving certain groups feeling resentful and others feeling entitled. Act proponents have re-termed this result as shared responsibility, but there cannot be shared responsibility when the burden is harbored only by some. The outcome is an uneven distribution of the economic burden as the reciprocal gains for certain parties are obsolete.

Individuals are willing to make deals for the greater good only because there are others reciprocating by making deals for their good as well. When these deals fall through, and some are given more than others, the breach breeds a culture and animosity and a loss of incentive for wealth creation. The Act creates a rather backwards outcome in that "[w] ealth generation is taken as an endeavor that can and should be harnessed to aid in producing the social changed believed are more beneficial for the greatest number of people."188 Rather, in order to be appropriately maintained, the contract should create an incentive for wealth creation. The Act produces the opposite result by creating a culture of dependence. People will come to rely on the various government subsidies to supply insurance for their healthcare needs. Even though most people will not forgo the opportunity to be wealthy because part of their wealth will be used for someone else's healthcare, this concept flies in the face of fundamental fairness. The contract was meant to serve as a means that allowed each individual an equal opportunity for success in society. 
Therefore, each individual must be allowed to reap the benefits of what they have sown.

Lastly, the Act breaches the term of moral obligation by creating an obligation forced by law rather than stemming from morality. As explained, the Act creates a responsibility of the more well-off to account for the right of the less well-off. When the individual feels their own interests are becoming more threatened, there is a natural tendency to become more inclusive. People will promote the greater good when their own investments are adequately protected. By penalizing the income-producing members in the contract, the Act creates a further disincentive to consider the general welfare. The opposite result will be brought out - individuals will exclusively look out for their own needs. Because the government has failed to protect certain individual interests, the task is taken on by each individual party. It is human nature that people will care for others when they are not forced to do so. Individuals do what is right by others when they feel secure in their place in society. Charitable tendencies are exhibited when individuals are permitted to act according to their own conscious. When the law is structured so as to obligate people to start giving up their own property, people become insecure and less willing to let go of their property on their own accord. As such, when individual citizens are permitted to govern themselves without outside intervention, they respect the moral claims of other members in the collective society. ${ }^{189}$

\section{PART V: CONCLUSION: HEALTHCARE REFORM \& RENEGOTIATION OF THE SOCIAL CONTRACT}

Many proponents of the Act call for a "renegotiation of the social contract"-in essence, a new social contract. ${ }^{190}$ They argue that current economic conditions call for further enlargement of the public sector to correct certain social failures and inequities. ${ }^{191}$ However, as we have seen, with a resulting domination of the public sector, the social contract becomes non-existent. Where there is no balance between the individual and the community, the individual has no incentive to be bound by larger community interests. Therefore, I would argue the remedy would call for renegotiation in the reverse.

189. McAffee, supra note 47, at 598.

190. See Robert Rich, Health Policy, Health Insurance and the Social Contract, 21 Comp. LaB. L. \& POL'Y J. 397 (2000).

191. Id. 
While renegotiation is needed, such renegotiation must revert back to the basics on which the social contract was originally built. If we are to restore the American idea of the social contract, we need to return to the basic principles of mutual obligation within a framework that is financially responsible and just. ${ }^{192}$ Healthcare for those in need can be provided for without attempting to create a natural right and abusing the social contract. The social contract cannot exist for the protection of a natural right when such a natural right does not exist. This causes the initial breakdown. Consequently, there cannot be a forced natural right to healthcare when one does not occur naturally. As argued by Locke, we cannot view any right granted to an individual in a vacuum, for it comes with a corresponding duty. ${ }^{193}$ Therefore, in the terms of healthcare, any grant by the government for assistance must come with a corresponding individual responsibility to care for and maintain one's own life.

Furthermore, the creation of a right to healthcare robs the nation of one of the benefits of federalism-allowing states to act as laboratories, testing different solutions to determine which will rise to the top. The Act places the flexibility of policymakers in a state of paralysis; it inhibits legislators from remaining innovative when responding to the problems of the day. ${ }^{194}$ Explained by others, "[h]ealthcare as a right leaves little room for democratic debate or compromise since the point of a right is to remove an issue from the realm of majority rule. It would mandate a 'wrenching' economic and social dislocation in order to promote the private benefit of the $12 \%$ of Americans who do not have health insurance at any given time." 195

Nonetheless, perhaps health care could be regarded as necessary to affect the natural right to life or the pursuit of happiness, and consequently, it should be treated as a natural right under the social contract even as renegotiated. This formulation, too, is greatly flawed. There lies a distinction between the right to healthcare and the right to "Life, Liberty and the Pursuit of Happiness." While it may be true that the existence of healthcare would enhance a person's right to life and liberty, it does not follow that the denial of healthcare will thereby result in a denial of those rights as well. Therefore, the social contract will not deny any healthcare — or the right to a healthy life.

192. See Stuart M. Butler, Restoring the American Social Contract (July 26, 2007), The Herit AGE Foundation (Aug. 29, 2007), http://www.heritage.org/Research/Lecture/Restoring-the-American-SocialContract (arguing for healthcare reform based on reciprocal obligations).

193. Zuckert, supra note 58, at 727.

194. Busch, supra note 154 .

195. Id. 
But, at the same time, the social contract will not guarantee healthcare. Any further reform of healthcare must be based upon fair community consent, individual responsibility, and reciprocity. 